\title{
ACUTE CENTRAL AND PERIPHERAL ANALGESIC ACTIVITY OF ETHANOLIC EXTRACT OF THE LEAVES OF CLERODENDRUM VISCOSUM (EECV) IN RODENT MODELS
}

\author{
Rajan Chandrashekar, Sudarshanram Narayan Rao* \\ Dept of Pharmacology, Yenepoya Medical College, Yenepoya University, Derlakette, Mangalore 575018, India \\ *Corresponding author's Contact No. : 9483787982, E-mail: chandumoon47@gmail.com
}

Received 13 July 2012; Review Completed 04 Aug 2012; Accepted 14 aug 2012, Available online 15 Sep 2012

\begin{abstract}
Pain, inflammation and pyrexia are the most common disturbing symptom a person experiences in life. Numerous drugs are available in the market for relieving these symptoms and which are sold over the counter. However they have high tendency of having adverse drug reaction from a trivial nausea and vomiting to gastric irritation leading to peptic ulcer, perforation and even death. The aim of the study was to investigate the acute peripheral activity of Ethanolic Extract of the leaves of Clerodendrum viscosum (EECV) by acetic acid induced writhing reflex test in mice and acute central analgesic activity by tail immersion method in rats. Dried powdered leaves of Clerodendrum viscosum were subjected to solvent extraction by using $90 \%$ ethanol. Based on acute oral toxicity study according to Organization for Economic Cooperation and Development (OECD) guidelines No. 423 , three doses of the test drug was selected $(100,200 \& 400 \mathrm{mg} / \mathrm{kg}$ for mice) and $(75,150 \& 300 \mathrm{mg} / \mathrm{kg}$ for rats), and were subjected to acute analgesic activity. The EECV showed significant $(\mathrm{p}<0.01)$ acute peripheral analgesic activity in mice in the dose of $200 \mathrm{mg} / \mathrm{kg}$ as compared to control but failed to show any central analgesic activity by tail immersion method at any of the three doses selected compared to control in rats.
\end{abstract}

Keyword: Analgesic, Clerodendrum viscosum, Ethanolic extract, Tail immersion test, Writhing reflex test.

\section{INTRODUCTION}

Pain, inflammation and fever are very common complications in day to day life of human beings. Several plants and their products are found and proved to possess analgesic and antipyretic property. ${ }^{1}$ The practice of herbal medicine dates back to the very earliest period of known human history. There are evidences of herbs having been used in the treatment of diseases and for revitalizing body system in almost all ancient civilization. Ayurveda, the Science of Life, has provided important and rationale basis for treatment of various ailments. ${ }^{2}$ Plants are always a indispensable sources of medicine since time immemorial. Studies on natural product are aimed to determine medicinal values of plants by exploration of existing scientific knowledge, traditional uses and discovery of potential chemotherapeutic agents in day to day life. Phytochemicals are used as templates for lead optimization programs, which are intended to make safe and effective drugs. ${ }^{3}$ The genus Clerodendrum L. (Family: Verbenaceae) is very widely distributed in tropical and subtropical regions of the world. More than five hundred species of the genus are identified till now, which includes small trees, shrubs and herbs. Ethno-medical importance of various species of Clerodendrum genus has been reported in various indigenous systems of medicines and as folk medicines. The genus is being used as medicines specifically in Indian, Chinese, Thai, Korean, Japanese systems of medicine for the treatment of various life threatening diseases such as syphilis, typhoid, cancer, jaundice and hypertension. Few species of the genus like Clerodendrum inerme, $C$. thomosonae, $C$. indicum, and $C$. speciosum are ornamental and being cultivated for aesthetic purposes. The powder/paste form and the various extracts of root, stem and leaves are reported to be used as medicine for the treatment of asthma, cataract, malaria, diseases of blood, skin and lung. To prove these ethno-medical claims, some of these species are being extensively studied for their biological activities using various animal models. The biological, isolation and identification studies of chemical constituents and its correlation with the biological activities of the genus Clerodendrum has also been studied. The chemical components in the reported from the genus Clerodendrum are phenolics, steroids, Di terpenes and triterpenes, flavonoids, volatile oils, etc. ${ }^{4}$

\section{MATERIALS AND METHODS}

Institutional Animal ethical committee approval was obtained from Yenepoya University before conducting the experiments.

\section{Animals:}

Equal number of Swiss albino mice weighing 25-30 g were divided into 5 groups having 10 animals in each group (5 males \& 5 females) for acetic acid induced writhing reflex test in mice (Table-I) and equal number of male and female Wistar albino rats weighing 150 - $200 \mathrm{~g}$ were taken and divided into 5 groups having 10 animals in each group (5 males \& 5 females) for tail immersion test in rats (Table-II). All animals were maintained in standard conditions at room temperature and relative humidity at $60+5 \%$ for 12 hours light dark cycle before the start of the experiment for seven days. Animals were handled carefully according to Committee for the purpose of Control and Supervision of Experiments on Animals (CPCSEA) guidelines. 
Table 1: Shows division of selected animals into 5 groups of 10 mice each $(5+5)$, the dose for each group and the number of days to be housed for acetic acid induced writhing reflex test in mice

\begin{tabular}{lcccc}
\hline Groups & Drug / Dose & Male & Female & $\begin{array}{c}\text { No. of days animals were } \\
\text { housed }\end{array}$ \\
\hline Group I & Control (Gum acacia $\%)(3 \mathrm{ml} / \mathrm{kg})$ & 5 & 5 & 10 \\
Group II & Indomethacin $(10 \mathrm{mg} / \mathrm{kg})$ & 5 & 5 & 10 \\
Group III & EECV $(100 \mathrm{mg} / \mathrm{kg})$ & 5 & 5 & 10 \\
Group IV & EECV $(200 \mathrm{mg} / \mathrm{kg})$ & 5 & 5 & 10 \\
Group V & EECV $(400 \mathrm{mg} / \mathrm{kg})$ & 5 & 5 & 10 \\
\hline
\end{tabular}

Table II: Shows division of selected animals into 5 groups of 10 rats each $(5+5)$, the dose for each group and the number of days to be housed for tail immersion test in rats.

\begin{tabular}{|c|c|c|c|c|}
\hline Group & Drug / Dose & Male & Female & $\begin{array}{c}\text { No. of days animals were } \\
\text { housed }\end{array}$ \\
\hline Group I & Control (Gum acacia 1\%) (3ml/kg) & 5 & 5 & 10 \\
\hline Group II & Pentazocin $(30 \mathrm{mg} / \mathrm{kg})$ & 5 & 5 & 10 \\
\hline Group III & $\operatorname{EECV}(75 \mathrm{mg} / \mathrm{kg})$ & 5 & 5 & 10 \\
\hline Group IV & $\operatorname{EECV}(150 \mathrm{mg} / \mathrm{kg})$ & 5 & 5 & 10 \\
\hline Group V & $\operatorname{EECV}(300 \mathrm{mg} / \mathrm{kg})$ & 5 & 5 & 10 \\
\hline
\end{tabular}

\section{Plant material:}

The leaves of the plant Clerodendrum viscosum was collected from rural region of Manjanady in Mangalore region in the month of Sept-Nov 2010. It was authenticated by Dr. Krishna Kumar, Chairman, Dept of Applied Botany, Mangalore University, Mangalore. The herbarium of the plant (voucher specimen no YU/CV/2010) has been deposited at Yenepoya University, Mangalore.

\section{Drugs and Chemicals}

The drugs and chemicals were Indomethacin, Pentazocin (Yenepoya pharmacy, Mangalore), Gum acacia, Ethanol (Rajesh chemicals, Mumbai)

\section{Extraction:}

Leaves of Clerodendrum viscosum were carefully separated, cleaned, shade dried, mechanically grinded and coarsely powdered. About $125 \mathrm{gm}$ of air dried powdered material was extracted with $90 \%$ ethanol in a soxhlet extractor for 36 hours. It was concentrated to dryness under reduced pressure and controlled temperature $\left(40-50^{\circ} \mathrm{C}\right)$ using rotary evaporator. The ethanolic extract yielded a green Sticky mass weighing $125 \mathrm{~g}$. The ethanolic extract was concentrated by vacuum distillation to dryness; the yield obtained was $12.5 \% \mathrm{w} / \mathrm{w}$ with respect to dried leaf. The collected leaf extract was stored in a desiccator. A suspension of the extract prepared in $1 \%$ gum acacia was used in experimental studies. 5

\section{Acute Toxicity Studies}

As there was no references for the dose of Clerodendrum viscosum, the leaves of EECV was studied for acute oral

Table III: Showing analgesic effects of Ethanolic Extract of the leaves of Clerodendrum viscosum (EECV)_by acetic acid induced writhing reflex in mice (Acute Study)

\begin{tabular}{|c|c|c|}
\hline Treatment & Number of writhing (Mean \pm SEM) & $\%$ Inhibition \\
\hline Control (Gum acacia 1\%) $(3 \mathrm{ml} / \mathrm{kg})$ & $29.6 \pm 0.81$ & - \\
\hline Indomethacin $(10 \mathrm{mg} / \mathrm{kg})$ & $14.8 \pm 0.64 * * *$ & 50 \\
\hline EECV ( $100 \mathrm{mg} / \mathrm{kg})$ & $26.6 \pm 2.02 *$ & 10.13 \\
\hline EECV ( 200 mg/kg) & $16.4 \pm 1.39 * * *$ & 44.59 \\
\hline EECV ( 400 mg/kg) & $28.7 \pm 0.85^{*}$ & 3.04 \\
\hline
\end{tabular}
as devord of any toxicity in mice when given in was devoid of any toxicity in mice when given in doses up $2000 \mathrm{mg} / \mathrm{kg}$ by oral route. Its $1 / 5^{\text {th }}$ (i.e. $400 \mathrm{mg} / \mathrm{kg}$ ) \& $1 / 10^{\text {th }}$ (i.e. $200 \mathrm{mg} / \mathrm{kg}$ ) and $1 / 20^{\text {th }}$ (i.e. $100 \mathrm{mg} / \mathrm{kg}$ ) of 2000 $\mathrm{mg} / \mathrm{kg}$ were used to test for analgesic activity in mice and $75 \mathrm{mg} / \mathrm{kg}, 150 \mathrm{mg} / \mathrm{kg} \& 300 \mathrm{mg} / \mathrm{kg}$ were used to test for analgesic activity in rats (Dose conversion from mice to rat).

Acetic acid induced writhing reflex of Ethanolic Extract of the leaves of Clerodendrum viscosum (EECV) in mice:

In this method, mice in groups of 10 each were treated with vehicle (1\% gum acacia, orally) $(10 \mathrm{ml} / \mathrm{kg}$, orally), EECV (75 mg/kg, $150 \mathrm{mg} / \mathrm{kg} \quad \& \quad 300 \mathrm{mg} / \mathrm{kg}$ orally), and Indomethacin (10 mg/kg orally) was used as positive control. Analgesic activity of EECV was assessed by counting the number of writhes induced by $0.6 \%(10 \mathrm{ml} / \mathrm{kg}$ Intraperitonially) of acetic acid. Numbers of writhes per animal were counted following $10 \mathrm{~min}$. For acute study the animals received the drug 1 hour before conducting the experiment. A writhe was considered when animal showed contraction of abdomen with simultaneous stretching of at least one hind limb The formula for computing percent inhibition is: average writhes in the control group minus writhes in the drug group divided by writhes in the control group times $100 \%$. The total time period with the greatest percent of inhibition is considered the peak time. A dose range is reserved for interesting compounds or those which inhibit writhing more than $70 \%$. Compounds with less than $70 \%$ inhibition are considered to have minimal activity. (Table-III). ${ }^{7,8}$ 
Analgesic effects of Ethanolic Extract of leaves of Clerodendrum viscosum (EECV) by tail immersion method in rats:

In this method, the rats in each group treated with vehicle (1\% gum acacia, p.o) $10 \mathrm{ml} / \mathrm{kg}$, EECV (75 mg/kg, 150 $\mathrm{mg} / \mathrm{kg}$, \& $300 \mathrm{mg} / \mathrm{kg}$ orally), and pentazocin $(30 \mathrm{mg} / \mathrm{kg}$, Intraperitonially) was used as positive control. For acute study the animals received the drug 1 hour before conducting the experiment. They were placed in individual restraining cages leaving the tail hanging out freely. The distal $1-2 \mathrm{~cm}$ of tail was immersed in water and maintained at $55 \pm 0.5^{\circ} \mathrm{C}$. Time taken by the each rat to withdraw the tail from hot water was noted as reaction time. The reaction time noted before the administration of the drug was noted as zero minute. The cut off time to withdraw the tail was kept as 10 seconds. The mean reaction time was recorded for each group and compared between the groups (Table-IV).

Table IV: Showing analgesic Ethanolic Extract of leaves of Clerodendrum viscosum (EECV)_by tail immersion method in rats (Acute Study)

\begin{tabular}{|c|c|c|c|c|c|c|c|}
\hline Drugs & $\begin{array}{c}\text { Time } \\
\text { (0min) }\end{array}$ & $\begin{array}{c}\text { Time } \\
\text { (30min) }\end{array}$ & $\begin{array}{c}\text { Time } \\
\text { (60min) }\end{array}$ & $\begin{array}{c}\text { Time } \\
\text { (120min) }\end{array}$ & $\begin{array}{c}\text { Time } \\
\text { (180min) }\end{array}$ & $\begin{array}{c}\text { Time } \\
(240 \mathrm{~min})\end{array}$ & $\begin{array}{c}\text { Time } \\
\text { (360min) }\end{array}$ \\
\hline $\begin{array}{c}\text { Control (Gum acacia } 1 \%) \\
(3 \mathrm{ml} / \mathrm{kg})\end{array}$ & $\begin{array}{c}1.13 \pm \\
0.08\end{array}$ & $\begin{array}{c}1.12 \pm \\
0.04\end{array}$ & $\begin{array}{c}1.18 \pm \\
0.09\end{array}$ & $\begin{array}{l}1.20 \pm \\
0.05\end{array}$ & $\begin{array}{c}1.30 \pm \\
0.09\end{array}$ & $\begin{array}{c}1.29 \pm \\
0.09\end{array}$ & $\begin{array}{c}1.19 \pm \\
0.03\end{array}$ \\
\hline $\begin{array}{c}\text { Standard } \\
\text { (Pentazocine) } \\
(30 \mathrm{mg} / \mathrm{kg})\end{array}$ & $\begin{array}{l}1.13 \pm \\
0.02 *\end{array}$ & $\begin{array}{c}5.01 \pm \\
0.11 * * *\end{array}$ & $\begin{array}{c}5.26 \pm \\
0.15 * * *\end{array}$ & $\begin{array}{c}5.60 \pm \\
0.39 * * *\end{array}$ & $\begin{array}{c}5.47 \pm \\
0.15^{* * *}\end{array}$ & $\begin{array}{c}5.46 \pm \\
0.21 * * *\end{array}$ & $\begin{array}{c}4.52 \pm \\
0.11 * * *\end{array}$ \\
\hline EECV(75mg/kg) & $\begin{array}{l}1.16 \pm \\
0.04 *\end{array}$ & $\begin{array}{l}1.46 \pm \\
0.08^{*}\end{array}$ & $\begin{array}{l}1.43 \pm \\
0.06^{*}\end{array}$ & $\begin{array}{l}1.41 \pm \\
0.08^{*}\end{array}$ & $\begin{array}{l}1.16 \pm \\
0.03 *\end{array}$ & $\begin{array}{l}1.18 \pm \\
0.04 *\end{array}$ & $\begin{array}{l}1.29 \pm \\
0.08^{*}\end{array}$ \\
\hline $\operatorname{EECV}(150 \mathrm{mg} / \mathrm{kg})$ & $\begin{array}{l}1.43 \pm \\
0.09^{*}\end{array}$ & $\begin{array}{l}1.48 \pm \\
0.09 *\end{array}$ & $\begin{array}{l}1.32 \pm \\
0.09 *\end{array}$ & $\begin{array}{l}1.48 \pm \\
0.07 *\end{array}$ & $\begin{array}{l}1.43 \pm \\
0.06^{*}\end{array}$ & $\begin{array}{l}1.28 \pm \\
0.05^{*}\end{array}$ & $\begin{array}{l}1.27 \pm \\
0.08 *\end{array}$ \\
\hline EECV (300 mg/kg) & $\begin{array}{l}1.27 \pm \\
0.10^{*}\end{array}$ & $\begin{array}{l}1.17 \pm \\
0.02 *\end{array}$ & $\begin{array}{l}1.08 \pm \\
0.01 *\end{array}$ & $\begin{array}{l}1.28 \pm \\
0.11 *\end{array}$ & $\begin{array}{l}1.26 \pm \\
0.05 *\end{array}$ & $\begin{array}{l}1.33 \pm \\
0.08 *\end{array}$ & $\begin{array}{l}1.17 \pm \\
0.03 *\end{array}$ \\
\hline
\end{tabular}

\section{STATISTICAL ANALYSIS}

The observations are mean \pm S.E.M. and analyzed by one way ANOVA followed by Dunnett's multiple comparison test. $\mathrm{p}<0.05$ was considered statistically significant

\section{RESULTS AND DISCUSSION}

Pain, inflammation and pyrexia are the most common disturbing symptom in day to day life. Numerous drugs are available in the market for relieving these symptoms and which are sold over the counter. However they have high tendency of having adverse drug reaction from a trivial nausea and vomiting to gastric irritation leading to peptic ulcer, perforation and even death.

The main undesirable side-effects of aspirin (Irreversible COX inhibitors) taken by mouth are gastrointestinal ulcers, stomach bleeding, and tinnitus, especially in higher doses. In children and adolescents, aspirin is no longer indicated to control flu-like symptoms or the symptoms of chickenpox or other viral illnesses, because of the risk of Reye's syndrome. ${ }^{10}$ Reversible COX inhibitors have not shown any superiority over aspirin in therapeutic effects of safety in over dose. Nimesulide has been banned in most western country due to its hepatotoxic effects. Even though paracetamol is commonly prescribed analgesic and antipyretic drug, but it lacks anti inflammatory effects and also not safe in over dose. Selective COX 2 inhibitors have been least prescribed in last few years due to its adverse cardiac events and many have been withdrawn from the market. ${ }^{11}$ Corticosteroids have anti inflammatory effects, but lacks analgesic and antipyretic effects. Moreover the long term administration of corticosteroids has its own adverse effects and also delays wound healing process. ${ }^{12}$ Opoids even though analgesic but lacks anti-inflammatory and antipyretic effects and not used
EECV-Ethanolic Extract of the leaves of Clerodendrum viscosum for simple pain due to its abuse and dependence liability. ${ }^{13}$ Southern part of our country has a tradition of using herbal preparation from centuries especially in dakshin kannad (Mangalore) district. However no scientific data are available for many herbal drugs which are locally used. Hence evaluating these drugs, it would be worthwhile to have scientific approach of using them. Hence in this study, an indigenous plant called Clerodendrum viscosum mentioned in Charaka and Sushruta treaties as an analgesic, anti-inflammatory and antipyretic drug and also in folk medicine. ${ }^{14}$

As EECV was devoid of any toxicity in mice when given in doses up to $2000 \mathrm{mg} / \mathrm{kg}$ by oral route, its $1 / 5^{\text {th }}$ (i.e. 400 $\mathrm{mg} / \mathrm{kg}$ ) and $1 / 10^{\text {th }}$ (i.e. $200 \mathrm{mg} / \mathrm{kg}$ ) and $1 / 20^{\text {th }}$ (i.e. 100 $\mathrm{mg} / \mathrm{kg}$ ) of $2000 \mathrm{mg} / \mathrm{kg}$ was used to test for peripheral analgesic activity in mice and $75 \mathrm{mg} / \mathrm{kg}, 150 \mathrm{mg} / \mathrm{kg}$ and 300 $\mathrm{mg} / \mathrm{kg}$ was used to test for central analgesic activity in rats.

The present study has shown that the Ethanolic Extract of the leaves of Clerodendrum viscosum (EECV) at dose $200 \mathrm{mg} / \mathrm{kg} \quad(\mathrm{p}<0.01) \quad$ exhibited significant peripheral analgesic activity in mice compared to control (Table III). But, it did not show any significant central analgesic activity by tail immersion method when compared to control any of the three doses selected in rats (Table IV).

However further studies are needed to evaluate its exact mechanism of action for its peripheral analgesic activity.

\section{ACKNOWLEDGEMENT}

The first author is thankful to Dr. S. N Rao, Senior Professor \& Head, Dept of Pharmacology, and Yenepoya University for providing the support to conduct this experimental research. 
1. B.K. Nanda, J. Jena, B.Rath, B.R.Behera. Analgesic and Antipyretic activity of whole parts of Sphaeranthus indicus Linn. Journal of Chemical and Pharmaceutical Research, 2009, 1 (1): 207-212.

2. Balunas MJ, Kinghorn. Drug discovery from medicinal plants. Life Sci., 2005; 78: 431-441.

3. Hedge IC, Nasir YJ, Ali SI. Flora of Pakistan. University of Karachi, Department of Botany, Karachi, 1990; 192.

4. Shrivastva N, Patel T.Clerodendrum and Heathcare: An Overview. Medicinal and Aromatic Plant Science and Biotechnology 2007; 1(1), 142-

5. G. Prakash, Rajalakshmi. V, Thirumoorthy. N, Ramasamy. P, Selvaraj. S. Antioxidant activity of ethanolic extracts of Clerodendrum viscosum vent and Biophytum condolleanum wight. Der Pharmacia Lettre 2011: 3 (4)248-251

6. H. Gerhard Vogel. Chapter H. Analgesic, antiinflammatory, and anti-pyretic activity. In: Drug discovery and evaluation: pharmacological assays. $2^{\text {nd }}$ ed. Germany: Springer-Verlag Berlin Heidelberg; 2002.p. 716

7. Shinde NV, Kanase KG, Shilimkar VC, Undale VR, Bhosale AV. Antinociceptive and Anti-Inflammatory Effects of Solvent Extracts of Tagetes erectus Linn (Asteraceae). Tropical J Pharm Res 2009; 8:325-329.
8. Ndebia EJ, Kamgang R, Nkeh Chungaganye BN. Analgesic and anti-inflammatory properties of aqueous extract from leaves of solanum torvum (solanaceae). African $\mathrm{J}$ traditional 2007; 4:240-244.

9. Ghosh MN, Evaluation of Analgesic activity: Fundamentals of experimental pharmacology, 2nd ed., Scientific book Agency, Calcutta, (2005) 69-71.

10. Macdonald $S$ "Aspirin use to be banned in under 16 year olds". BMJ. 2002; 325 (7371): 988.

11. Kearney P M, Baigent C, Godwin J, Halls H, Emberson J R, Patrono C. "Do selective cyclo-oxygenase-2 inhibitors and traditional non-steroidal anti-inflammatory drugs increase the risk of atherothrombosis? Meta-analysis of randomized trials" BMJ (Clinical research ed.) 2006; 332

12. Mehlisch DR. "The efficacy of combination analgesic therapy in relieving dental pain".Journal of American Dental Association. 2002133 (7): 861-71.

13. Janssen P, Niemegeers CJE, Dony JGH. The inhibitory effect of fentanyl and other morphine like analgesics on the warm water induced tail withdrawl reflex in rats. Arzneim Forsch.1963; 13:502-507

14. Sharma HK, Chhangte L, Dolui AK. "Traditional medicinal plants in Mizoram, India". Fitoterapia.2001; 72 (2): 146-161 